\title{
PENGARUH BIAYA PROMOSI DAN BIAYA DISTRIBUSI TERHADAP HASIL PENJUALAN PRODUK BAWANG GORENG PADA UD BAWANG GORENG DI DESA PAGEDANGAN KECAMATAN ADIWERNA KABUPATEN TEGAL
}

\author{
Darnawi, Jaka Waskito, dan Mahben Jalil \\ Program Studi Manajemen \\ Fakultas Ekonomi Universitas Pancasakti
}

\begin{abstract}
The purpose of this study is 1). To know the effect of promotion cost to the sale result, 2). To know the effect of distribution cost on sales result, 3). To know the effect of promotion cost and distribution cost together to the sales result. Data collection techniques used in this study is the method of documentation and interviews. While the data analysis method used is classical assumption test, simple linear regression analysis, test of simple linear regression coefficient, multiple linear regression analysis, test of multiple linear regression coefficient, coefficient of determination. Based on the results of simple linear regression analysis calculations obtained results for the promotion variable in obtaining a probability significance value of 0.000 is smaller than 0.05 means there is a significant effect of promotion on sales results concluded that the first hypothesis that reads "Suspected there is the influence of promotional costs on sales results fried onion product "proved true. The result of calculation of simple linear regression analysis obtained result for the distribution variable in obtaining the value of probability significance of 0.000 is smaller than 0,05 meaning there is significant influence of distribution to result of sale can be concluded that second hypothesis which reads "allegedly there influence of distribution cost to result of sale fried onion product "is proven. The result of simultaneous influence test obtained by the significance level of 0,000<0,05 means there is a significant influence between the cost of promotion and distribution costs together to the sales results can be said the third hypothesis that reads "It is suspected that there is influence of promotion costs and distribution costs together. same to the sale of onion garlic products on UD Bawang Goreng in Pagedangan Village Adiwerna District Tegal Regency "proved true.
\end{abstract}

Keywords: Promotion Cost, Distribution Cost, Sales Result

\section{PENDAHULUAN}

Latar Belakang Masalah

Perkembangan dunia usaha yang sedemikian pesat telah menimbulkan persaingan setiap perusahaan dalam memasarkan produknya, khususnya kondisi pasar yang ada pada saat ini penuh dengan berbagai macam produk yang ditawarkan. Keadaan ini menuntut perusahaan-perusahaan yang ada untuk lebih meningkatkan kualitas produk dalam menghadapi pesaing atau memperbaiki sistem pemasarannya yang tidak sesuai dengan perkembangan jaman sekarang ini serta untuk menghadapi para pesaing yang lebih pandai dalam memasarkan barangnya. Untuk itu setiap perusahaan dituntut 
untuk lebih mampu mengimbangi laju perubahan yang terjadi terutama yang menyangkut persaingan di dalam memasarkan produknya.

Agar perusahaan tetap mampu bersaing dengan perusahaan lain yang menjual produk sejenis, maka manajemen perusahaan harus mampu mengelola perusahaannya dengan baik, supaya konsumen atau pelanggan tidak beralih kepada perusahaan lain dan melakukan pembelian ulang secara terus menerus. Untuk itu perusahaan dituntut untuk lebih memahami segala kebutuhan dan keinginan konsumen atau perusahaan harus mampu menciptakan produk yang sesuai dengan kebutuhan dan keinginan konsumen. Selain itu juga diperlukan pemasaran yang baik agar konsumen yang ada menjadi loyal dan tidak beralih ke perusahaan lain. Konsep pemasaran menyatakan bahwa kunci meraih tujuan perusahaan adalah memuaskan kebutuhan dan keinginan konsumen.

Para pelaksana pemasaran harus berusaha untuk melaksanakan kegiatan yang bertujuan untuk meningkatkan hasil penjualan. Sehingga dalam menghadapi persaingan tersebut, perusahaan diharapkan dapat menentukan strategi pemasaran yang tepat. Di dalam menjalankan kegiatan usahanya, perusahaan sementara akan dihadapi dengan berbagai masalah yang timbul. Masalahmasalah ini sangat bervariasi dan kompleks sehingga harus diselesaikan secara sistematis dan efisien untuk mendapatkan hasil yang optimal. Akan tetapi dengan banyaknya produk yang ada di pasar, dapat menimbulkan masalah bagi perusahaan, yaitu bagaimana cara mempengaruhi konsumen agar bersedia membeli produk yang dihasilkan dan selalu menggunanakan produk mereka.

Suatu perusahaan memproduksi barang dengan kualitas yang baik, harga relative murah dibandingkan pesaing, dan secara luas tersebar ke berbagai tempat tetapi apabila calon pembeli tidak diberi tahu adanya produk tersebut, diingatkan atau dibujuk untuk membelinya, konsumen akan bisa membayingkan bahwa produk tersebut tidak akan bias laku dipasaran dan segala sesuatu yang telah dilakukan akan sia-sia.

Perusahaan yang baru berdiri pun harus mempromosikan produknya untuk memberitahukan bahwa dipasar ada produk baru, tetapi juga untuk produsen yang produknya mulai memasuki tahap pertumbuhan dalam siklus kehidupan produknya ini dapat menggunakan promosi yang sifatnya membujuk. Promosi yang sifatnya mengingatkan dilakukan terutama untuk mempertahankan merk dan image produk di hati konsumennya, dan ini perlu dilakukan selama tahap kedewasaan didalam siklus kehidupan barang atau jasa sebagai produksinya.

Dari uraian di atas menggambarkan betapa kompleksnya masalah promosi dalam suatu perusahaan, betapa pentingnya system dan strategi yang tepat dalam menyampaikan pesan kepada konsumennya dengan melalui media promosi yang biasanya menggunakan salah satu atau kombinasi dari variable-variabel promosi. Sudah pasti suatu perusahaan ingin selalu meningkatkan jumlah penjualannya untuk mendapatkan laba yang lebih besar, dan kita melihat betapa berperannya promosi dalam upaya untuk dapat mencapai tujuan perusahaan yaitu peningkatan volume penjualan. Di samping faktor promosi faktor lain yang tidak kalah pentingnya adalah saluran distribusi.

Saluran distribusi berperan sebagai suatu jalur yang dilalui oleh arus barangbarang dari produsen ke perantara dan akhirnya sampai kepada konsumen sebagai pemakai produk yang diproduksi. Syarat lain yang tidak boleh diabaikan oleh produsen adalah tersedianya 
produk, agar setiap saat dibutuhkan oleh konsumen yang bersangkutan dapat diperoleh dengan mudah dan cepat.

Kealpaan suatu perusahaan untuk dapat menyediakan produknya setiap saat dibutuhkan oleh konsumen, akan menimbulkan konsekuensi bahwa loyalitas konsumen terhadap merk produknya menurun, yang disebabkan karena banyaknya produk subtitusi sempurna yang mempunyai kualitas dan harga yang bersaing dengan produk perusahaan yang bersangkutan. Seandainya kealpaan ini sering terjadi di suatu perusahaan, maka loyalitas konsumen terhadap merk produk tertentu pada akhirnya akan semakin menurun dan kemungkinan konsumen bisa berpindah pada merk produk yang lain.

Saluran distribusi harus dilaksanakan dengan tepat dan teratur, sehingga dapat diharapkan produk-produk yang dihasilkan dapat terjual sebanyak mugkin sehingga produknya dapat bersaing dalam pasar dengan produk pesaingnya. Jadi dalam menentukan saluran distribusi perusahaan harus mempertimbangkan masalah harga, produk juga promosi yang dilakukan. Oleh karena itu saluran distribusi sepertinya mudah, tetapi dalam pelaksanaannya tidaklah semudah yang dibayangkan, sebab menyangkut tugas dan tanggung jawab yang tidak ringan.

Bawang merah adalah salah satu komoditas hortikultura yang digunakan sebagai bahan baku industri makanan, obat-obatan, dan penyedap masakan karena aroma dan rasanya yang khas. Bawang merah mempunyai potensi dan peluang yang cukup baik sebagai komoditas agribisnis, karena termasuk komoditas sayuran unggulan Indonesia. Sentra-sentra produksi bawang merah di Indonesia umumnya berasal dari Brebes, Tegal (Jawa Tengah) dan Probolinggo (Jawa Timur). Setelah dipanen bawang merah tidak dapat disimpan lama karena mudah rusak dan sulit dipertahankan dalam bentuk segar. Penanganan yang kurang baik akan menyebabkan kebusukan atau bahkan tumbuh di tempat penyimpanan. Diperlukan upaya penanganan pasca panen yang baik untuk memperpanjang masa simpan dan meningkatkan nilai ekonomi bawang merah, misalnya diolah menjadi bawang goreng. Cara tersebut dilakukan untuk mengangkat produksi sekaligus sebagai arah pengembangan komoditi bawang merah.

Permasalahan yang terjadi pada UD Bawang Goreng adalah adanya ketidakstabilan harga bahan baku, yaitu bawang merah. Harga bawang merah sebagai bahan baku bawang goreng berfluktuasi tergantung musin dan pasokan di pasar yang kondisinya di masing-masing daerah berbeda, sehingga seringkali terjadi perbedaan harga yang cukup signifikan antar daerah. Bawang merah termasuk komoditas yang tidak tahan lama. Mudah busuk jika disimpan terlau lama.

UD Bawang Goreng di Desa Pagedangan Kecamatan Adiwerna Kabupaten Tegal adalah salah satu usaha yang melakukan kegiatan produksi dengan menggunakan bahan baku bawang merah untuk menghasilkan bawang goreng. UD Bawang Goreng harus menentukan penyaluran distribusi dan kegiatan promosi yang tepat, efektif, dan efisien yang pada akhirnya dapat digunakan sebagai salah satu solusi untuk bersaing secara sehat sehingga mampu meningkatkan volume penjualan produk. Sementara itu dengan adanya aktivitas distribusi dan promosi yang dilakukan oleh UD Bawang Goreng maka menimbulkan biaya distribusi dan biaya promosi.

\section{Pertanyaan Penelitian}

Berdasarkan uraian latar belakang di atas, maka rumusan masalah di dalam penelitian ini adalah: 
Apakah ada pengaruh biaya promosi terhadap hasil penjualan produk bawang goreng pada UD Bawang Goreng di Desa Pagedangan Kecamatan Adiwerna Kabupaten Tegal ?

Apakah ada pengaruh biaya distribusi terhadap hasil penjualan produk bawang goreng pada UD Bawang Goreng di Desa Pagedangan Kecamatan Adiwerna Kabupaten Tegal ?

Apakah ada pengaruh biaya promosi dan biaya distribusi secara bersamasama terhadap hasil penjualan produk bawang goreng pada UD Bawang Goreng di Desa Pagedangan Kecamatan Adiwerna Kabupaten Tegal ?

Tujuan Penelitian
Tujuan yang ingin dicapai dalam penelitian adalah:

Untuk mengetahui pengaruh biaya promosi terhadap hasil penjualan produk bawang goreng pada UD Bawang Goreng di Desa Pagedangan Kecamatan Adiwerna Kabupaten Tegal.

Untuk mengetahui pengaruh biaya distribusi terhadap hasil penjualan produk bawang goreng pada UD Bawang Goreng di Desa Pagedangan Kecamatan Adiwerna Kabupaten Tegal.

Untuk mengetahui pengaruh biaya promosi dan biaya distribusi secara bersama-sama terhadap hasil penjualan produk bawang goreng pada UD Bawang Goreng di Desa Pagedangan Kecamatan Adiwerna Kabupaten Tegal.

\section{KERANGKA PEMIKIRAN DAN HIPOTESIS}

\section{Kerangka Pemikiran}

Kerangka berpikir dalam penelitian dalam ini digambarkan sebagai berikut

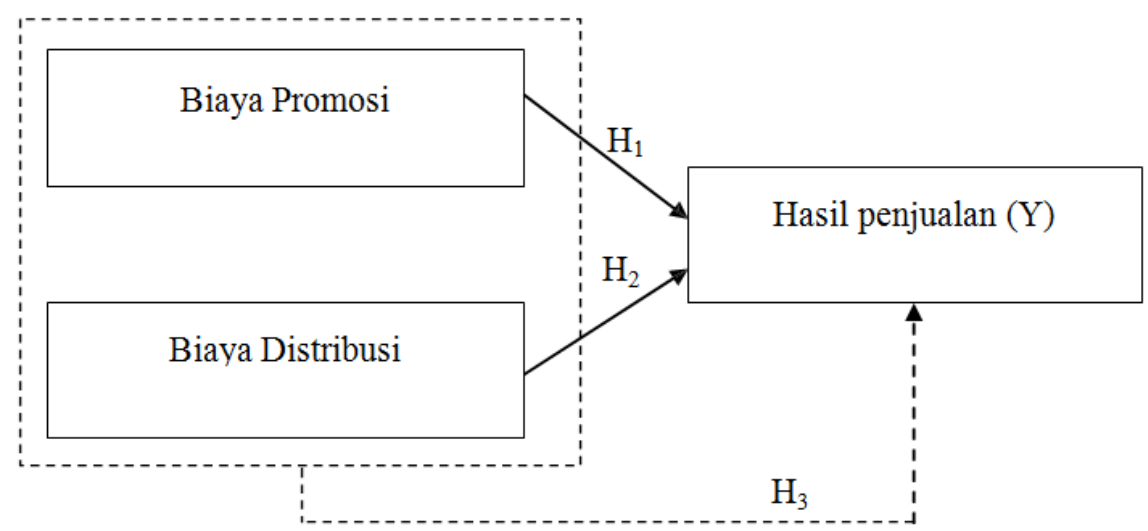

Gambar 1. Kerangka Pemikiran

\section{Hipotesis}

Hipotesis dalam penelitian ini adalah :

H1: Diduga terdapat pengaruh biaya promosi terhadap hasil penjualan produk bawang goreng pada UD Bawang Goreng di Desa Pagedangan Kecamatan Adiwerna Kabupaten Tegal.
H2: Diduga terdapat pengaruh biaya distribusi terhadap hasil penjualan produk bawang goreng pada UD Bawang Goreng di Desa Pagedangan Kecamatan Adiwerna Kabupaten Tegal.

H3: Diduga terdapat pengaruh biaya promosi dan biaya distribusi secara 
bersama-sama terhadap hasil penjualan produk bawang goreng pada UD Bawang Goreng di Desa Pagedangan Kecamatan Adiwerna Kabupaten Tegal

\section{METODE PENELTIAN}

\section{Variabel Penelitian}

Variabel-variabel yang akan diteliti adalah sebagai berikut :

Volume penjualan (Y) adalah hasil akhir yang dicapai perusahaan dari hasil penjualan produk yang dihasilkan oleh perusahaan. Data yang digunakan adalah data volume penjualan tahun 2015-2017, dalam bentuk data bulanan.

Biaya promosi (X1) adalah semua biaya yang dikeluarkan perusahaan untuk melaksanakan kegiatan promosi, seperti pembuatan leaflet, stiker, brosur, spanduk, kalender, serta mengikuti kegiatan pameran dan seminar. Data yang digunakan adalah biaya promosi tahun 20152017, dalam bentuk data bulanan.

Biaya distribusi (X2) adalah biaya yang dikeluarkan perusahaan untuk menyalurkan barang atau jasa kepada konsumen, dimana di dalamnya termasuk biaya transportasi. Data biaya distribusi dari tahun 20152017, dalam bentuk data bulanan.

\section{Teknik Pengumpulan Data}

Teknik pengumpulan data dalam penelitian ini adalah:

Dokumentasi

Dokumentasi adalah pengumpulan data untuk melihat data dengan jelas dan berhubungan dengan penelitian tentang perusahaan yang akan diteliti. Metode ini digunakan untuk mencari data dari perusahaan dengan meneliti sumbersumber tertulis yang berkaitan dengan obyek penelitian dan gambaran umum. Data yang diperoleh dari dokumentasi adalah Sejarah UD Bawang Goreng di Desa Pagedangan Kecamatan Adiwerna Kabupaten Tegal. Data biaya promosi tahun 2015-2017 (data bulanan). Data biaya distribusi tahun 2015-2017 (data bulanan). Data hasil penjualan tahun 2015-2017 (data bulanan)

Wawancara

Wawancara adalah suatu cara pengumpulan data yang berasal dari adanya tanya jawab dari penulis dan pemilik perusahaan. Informasi yang didapat untuk melengkapi data yang masih terdapat kurang jelasnya dokumentasi data yang diperoleh.

\section{Analisis Data dan Uji Hipotesis}

Teknik analisis data yang digunakan adalah pengujian asumsi klasik, analisis regresi linier berganda dan pengujian hipotesis dengan menggunakan Statistical Package for Social Science (SPSS) Ver 17.

Pengujian Asumsi Klasik

Suatu model regresi yang baik adalah model regresi yang memenuhi asumsi klasik yaitu, asumsi normalitas, multikolinieritas, autokorelasi dan heterokedastisitas. Oleh karena itu, perlu dilakukan pengujian normalitas, multikolinierritas, autokorelasi dan heterokedastisitas sebelum dilakukan pengujian hipotesis. Berikut penjelasan uji asumsi klasik yang akan dilakukan penelitian ini:

\section{Uji Normalitas}

Uji normalitas bertujuan untuk menguji apakah dalam model regresi variabel terikat dan variabel bebas keduanya memiliki distribusi normal atau tidak (Ghozali, 2016 : 74). Model regresi yang baik adalah memiliki distribusi data normal atau mendekati normal. Model regresi yang memenuhi asumsi normalitas 
apabila data tersebut menyebar di sekitar garis diagonal dan mengikuti arah garis diagonal.

\section{Uji Multikolinieritas}

Bertujuan untuk menguji apakah model regresi ditemukan adanya korelasi antar variabel bebas. Artinya antara variabel bebas yang terdapat dalam model memiliki hubungan yang sempurna bila terjadi maka antara variabel bebas terjadi korelasi, sehingga sulit diketahui variabel mana yang mempengaruhi. Menurut Ghozali (2016:57), suatu model regresi yang tidak terjadi gejala multikolinieritas jika nilai variance inflation factor (VIF) lebih kecil 10.

\section{Uji Autokorelasi}

Uji Autokorelasi dilakukan untuk menguji apakah dalam suatu model regresi linier ada korelasi antara kesalahan pengganggu pada periode $t$ dengan kesalahan pada periode t-1 (sebelumnya) (Ghozali, 2016 : 61). Untuk mendeteksi ada atau tidaknya problem autokorelasi pada model regresi dengan menggunakan uji Durbin-Watson (D-W test). Apabila nilai $\mathrm{D}-\mathrm{W}$ berada di antara $\mathrm{du}<\mathrm{d}<4$ - du berarti tidak ada korelasi.

\section{Uji Heteroskedrastisitas}

Uji heteroskedastisitas digunakan untuk menguji apakah dalam model regresi terjadi ketidaksamaan variance dan residual satu pengamatan ke pengamatan yang lain (Ghozali, 2016: 69). Model regresi yang baik adalah yang tidak terjadi heteroskedastisitas. Ada atau tidaknya problem heteroskedastisitas pada model regresi dapat dideteksi dengan melihat ada atau tidaknya pola tertentu yang teratur pada grafik scatterplot serta titik-titik menyebar di atas dan di bawah angka 0 pada sumbu Y.

\section{Analisis Regresi Linier Sederhana}

Analisis regresi linier sederhana digunakan untuk melihat besarnya pengaruh dari variabel bebas terhadap variabel terikat. Rumus yang digunakan untuk menghitung regresi linier adalah (Sugiyono, 2010:261):

$\hat{\mathrm{Y}}: \mathrm{a}+\mathrm{bX}$ Keterangan :

$\hat{\mathrm{Y}}=$ Variabel terikat $\mathrm{a}=$ Konstanta

$\mathrm{b}=$ Koefisien regresi linier $\mathrm{x}=$ Variabel bebas

Untuk melihat bentuk regresi antara variabel dengan persamaan regresi tersebut, maka nilai a dan $b$ harus ditentukan terlebih dahulu dengan rumus di bawah ini:

Untuk mengetahui nilai a, maka digunakan rumus:

$$
a=\frac{Y X^{2} X X Y}{n X^{2} X^{2}}
$$

Sedangkan untuk mengetahui nilai b, maka digunakan rumus :

$$
b=\frac{n X Y X Y}{n X^{2} X^{2}}
$$

\section{Uji Signifikansi Koefisien Regresi Linier Sederhana}

Uji signifikansi koefisien regresi linier sederhana menunjukkan seberapa jauh pengaruh satu variabel independen secara individu dalam menerangkan variabel dependen. Langkah-langkah pengujiannya yaitu:

Membuat hipotesis dalam bentuk statistik dan kalimat:

$$
\begin{aligned}
\text { Ho }: & \text { b1 }=0 . \text { Tidak terdapat } \\
& \text { pengaruh yang signifikan } \\
& \text { biaya promosi terhadap } \\
& \text { hasil penjualan. } \\
\text { H1 : } & \text { b1 } \neq 0 \text {, Terdapat pengaruh } \\
& \text { yang signifikan biaya } \\
& \text { promosi terhadap hasil } \\
& \text { penjualan. } \\
\text { Ho : } & \text { b2 }=0, \text { Tidak terdapat } \\
& \text { pengaruh yang signifikan }
\end{aligned}
$$


biaya distribusi terhadap hasil penjualan.

$\mathrm{H} 2: \mathrm{b} 2 \neq 0$, Terdapat pengaruh yang signifikan biaya distribusi terhadap hasil penjualan.

Menentukan taraf signifikansi $\alpha$

Untuk menguji signifikan dari koefisien korelasi yang diperoleh, akan digunakan uji t satu pihak dengan menggunakan tingkat signifikan sebesar $95 \%$ (atau $=5$ $\%$ ).

Kaidah pengujian

Jika - ttabel thitung ttabel maka terima Ho. Jika thitung ttabel atau thitung $<$ - ttabel maka tolak Ho.

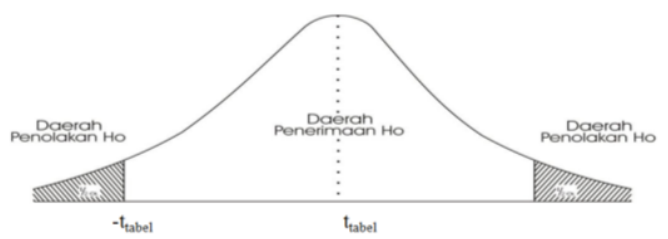

d. menghitung $t_{\text {hitung }}$

$$
\mathrm{t}_{\text {hitung }}=\frac{b}{S b}
$$

Keterangan :

$\mathrm{B}=$ Nilai Parameter

$\mathrm{Sb}=$ Standar Eror dari $\mathrm{b}$

\section{Kesimpulan Ho diterima atau}

ditolak

\section{Analisis Regresi Linier Berganda}

Analisis regresi pada dasarnya adalah studi mengenai ketergantungan variabel dependen (terikat) dengan satu atau lebih variabel independen, dengan tujuan untuk mengestimasi atau memprediksi rata-rata populasi atau nilai rata-rata variabel dependen berdasarkan nilai variabel independen yang diketahui. Adapun persamaan untuk menguji hipotesis secara keseluruhan pada penelitian ini adalah sebagai berikut (Sugiyono, 2010: 275):

$$
\hat{\mathrm{Y}} \quad: \mathrm{a}+\mathrm{b} 1 \mathrm{X} 1+\mathrm{b} 2 \mathrm{X} 2
$$

Keterangan :

$\hat{\mathrm{Y}} \quad$ : Hasil penjualan

a : Konstanta

b1-b2 : Koefisien Regresi

$\mathrm{X} 1$ : Biaya promosi

$\mathrm{X} 2$ : Biaya distribusi

\section{Uji Signifikansi Koefisien Regresi Linier Berganda}

Uji simultan (Uji F) menunjukkan apakah semua variabel independen yang dimasukkan dalam model mempunyai pengaruh secara simultan terhadap variabel dependen.

\section{Membuat hipotesis dalam bentuk statistik dan kalimat:}

Ho : $\mathrm{b} 1=\mathrm{b} 2=0 \quad$ Tidak terdapat pengaruh yang signifikan biaya promosi dan biaya distribusi secara bersama-sama terhadap hasil penjualan.

Ha : $b 1 \neq b 2 \neq 0$. Terdapat pengaruh yang signifikan biaya promosi dan biaya distribusi secara bersama-sama terhadap hasil penjualan.

\section{Menentukan taraf signifikansi $\alpha$}

Untuk menguji signifikan dari koefisien korelasi yang diperoleh, akan digunakan uji $\mathrm{F}$ pihak kanan dengan menggunakan tingkat signifikan sebesar $95 \%($ atau $=5 \%)$.

\section{Kaidah pengujian}

Jika Fhitung < Ftabel maka terima Ho.

Jika Fhitung $>$ Ftabel maka tolak Ho

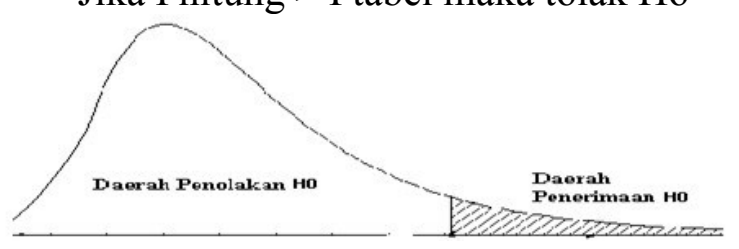




\section{Menghitung Fhitung}

Menghitung Fhitung dengan rumus (Sudjana, 2005: 187):

Fhitung $=\frac{J K_{\text {reg }} / k}{J K_{\text {res }} /(n-k-1)}$

Keterangan :

JKreg $=$ Jumlah Kuadrat regresi

JKres $=$ Jumlah Kuadrat residu

$\mathrm{k}=$ Jumlah varabel vevvas $\mathrm{n}$

$\mathrm{n}=$ Jumlah sampel

Dimana:

$J K_{(R \theta g)}=b_{1} \Sigma \mathrm{x}_{1} \mathrm{y}+b_{2} \Sigma \mathrm{x}_{2} \mathrm{y}+\cdots+b_{k} \Sigma \mathrm{x}_{\mathrm{k}} \mathrm{y}$

(Sudjana, 2005: 188) dan

$J K($ res $)=\Sigma(Y-\hat{Y})^{2}$ (Sudjana, 2005 : 188)

Yang akan lebih mudah jika dihitung dengan menggunakan :

$J K($ res $)=\Sigma y^{2}-J K($ Reg $)$

(Sudjana, 2005: 188)

\section{Kesimpulan Ho diterima atau} ditolak

\section{Koefisien Determinasi}

Nilai koefisien determinasi (R2) menunjukkan persentase pengaruh semua variabel independen secara simultan terhadap variabel dependen. Koefisien determinasi (R2) dapat dicari dengan formulasi: Besarnya koefisien determinasi adalah 0 sampai dengan 1 . Semakin mendekati nol, semakin kecil pula pengaruh semua variabel independen (X) terhadap nilai variabel dependen (dengan kata lain semakin kecil kemampuan model dalam menjelaskan perubahan nilai variabel dependen). Sedangkan jika koefisien determinasi mendekati satu, maka sebaliknya. Adapun rumus koefisien determinasi adalah sebagai berikut:

$\mathrm{KD}=\mathrm{r} 2 \times 100 \%$ Dimana:

KD: Besarnya koefisien determinasi

r: Koefisien Korelasi

\section{HASIL ANALISIS DATA DAN UJI HIPOTESIS}

Teknik analisis data yang digunakan adalah pengujian asumsi klasik, analisis regresi linier berganda dan pengujian hipotesis dengan menggunakan Statistical Package for Social Science (SPSS).

Ver 17.

\section{Pengujian Asumsi Klasik}

Suatu model regresi yang baik adalah model regresi yang memenuhi asumsi klasik yaitu, asumsi normalitas, multikolinieritas, autokorelasi dan heterokedastisitas. Oleh karena itu, perlu dilakukan pengujian normalitas, multikolinieritas, autokorelasi dan heterokedastisitas sebelum dilakukan pengujian hipotesis. Berikut penjelasan uji asumsi klasik yang akan dilakukan penelitian ini:

\section{Uji Normalitas}

Uji normalitas bertujuan untuk menguji apakah dalam model regresi variabel terikat dan variabel bebas keduanya memiliki distribusi normal atau tidak (Ghozali, 2016 : 74). Model regresi yang baik adalah memiliki distribusi data normal atau mendekati normal. Model regresi yang memenuhi asumsi normalitas apabila data tersebut menyebar di sekitar garis diagonal dan mengikuti arah garis diagonal.

\section{Dependent Variable: Hasil}

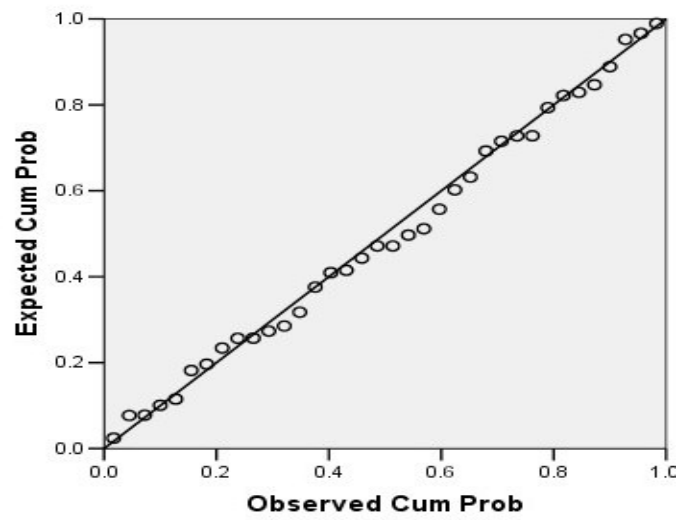

Gambar 7. Hasil Uji Normalitas 
Berdasarkan hasil dari uji normalitas pada penelitian ini dapat dilihat bahwa titik-titik menyebar di sekitar garis diagonal dan penyebaran mengikuti arah garis diagonal. Dengan demikian dapat dinyatakan bahwa penyebaran data mendekati normal atau memenuhi asumsi normalitas.

\section{Uji Multikolinieritas}

Bertujuan untuk menguji apakah model regresi ditemukan adanya korelasi antar variabel bebas. Artinya antara variabel bebas yang terdapat dalam model memiliki hubungan yang sempurna bila terjadi maka antara variabel bebas terjadi korelasi, sehingga sulit diketahui variabel mana yang mempengaruhi. Menurut Ghozali (2016:57), suatu model regresi yang tidak terjadi gejala multikolinieritas jika nilai variance inflation factor (VIF) lebih kecil 10.

Tabel 5. Hasil Uji Multikolinieritas

Coeffici entsa

\begin{tabular}{|c|c|c|c|c|c|c|c|}
\hline \multirow[b]{2}{*}{ Model } & \multicolumn{2}{|c|}{$\begin{array}{l}\text { Unstandardized } \\
\text { Coefficients }\end{array}$} & \multirow{2}{*}{$\begin{array}{l}\begin{array}{l}\text { Standardized } \\
\text { Coef f icients }\end{array} \\
\text { Beta }\end{array}$} & \multirow[t]{2}{*}{$\mathrm{t}$} & \multirow[t]{2}{*}{ Sig. } & \multicolumn{2}{|c|}{ Collinearity Statistics } \\
\hline & $\mathrm{B}$ & Std. Error & & & & Tolerance & VIF \\
\hline $1 \quad$ (Constant) & $-1885,665$ & 1707,515 & & $-1,104$ & ,277 & & \\
\hline Promosi & 6,043 & 1,943 & ,322 & 3,111 & 004, &, 147 & 6,814 \\
\hline Distribusi & 6,878 & 1,065 & ,669 & 6,460 &, 000 & 147 & 6,814 \\
\hline
\end{tabular}

a. Dependent Variable: Hasil.

Dari hasil perhitungan uji asumsi klasik terlihat untuk kedua variabel independen, angka VIF yaitu sebesar masing-masing 6,814 yang lebih kecil dari 10 sehingga tidak melebihi batas nilai VIF yang diperkenankan yaitu maksimal sebesar 10. Dengan demikian dapat disimpulkan bahwa model regresi tersebut tidak terdapat masalah multikolinearitas.

\section{Uji Autokorelasi}

Uji Autokorelasi dilakukan untuk menguji apakah dalam suatu model regresi linier ada korelasi antara kesalahan pengganggu pada periode $t$ dengan kesalahan pada periode t-1 (sebelumnya) (Ghozali, 2016 : 61). Untuk mendeteksi ada atau tidaknya problem autokorelasi pada model regresi dengan menggunakan uji Durbin-Watson (D-W test). Apabila nilai $\mathrm{D}-\mathrm{W}$ berada di antara du $<\mathrm{d}<4$ - du berarti tidak ada korelasi.

Tabel 6. Hasil Uji Autokorelasi Model Summaryb

\begin{tabular}{|c|c|c|c|c|c|}
\hline Model & R & $\begin{array}{c}\text { R } \\
\text { Square }\end{array}$ & $\begin{array}{c}\text { Adjusted } \\
\text { R Square }\end{array}$ & $\begin{array}{c}\text { St d. Error of } \\
\text { the Estimate }\end{array}$ & $\begin{array}{c}\text { Durbin- } \\
\text { Wat son }\end{array}$ \\
\hline 1 &, $974 \mathrm{a}$ &, 948 &, 945 & 1452,12526 & 1,596 \\
\hline
\end{tabular}

Dari hasil uji Durbin-Watson dengan menggunakan SPSS diperoleh hasil 1,596 yang berada diantara -2 sampai dengan +2 dengan demikian maka dapat disimpulkan bahwa tidak terdapat masalah autokorelasi pada model regresi

\section{Uji Heteroskedrastisitas}

Uji heteroskedastisitas digunakan untuk menguji apakah dalam model regresi terjadi ketidaksamaan variance dan residual satu pengamatan ke pengamatan yang lain (Ghozali, 2016: 69). Model regresi yang baik adalah yang tidak terjadi heteroskedastisitas. Ada atau tidaknya problem heteroskedastisitas pada model regresi dapat dideteksi dengan melihat ada atau tidaknya pola tertentu yang teratur pada grafik scatterplot serta titik-titik menyebar di atas dan di bawah angka 0 pada sumbu Y. 


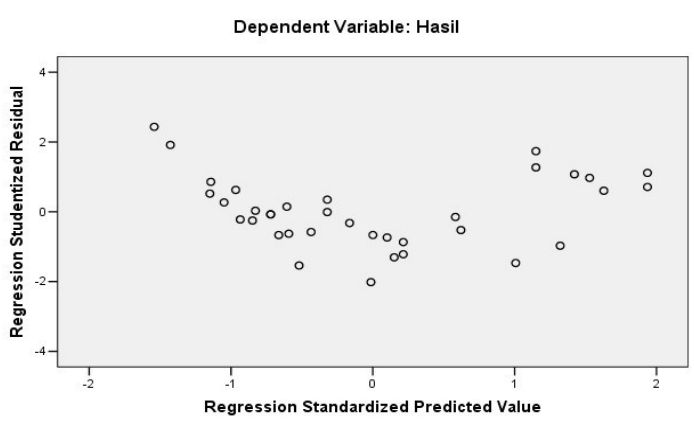

Berdasarkan grafik scatterplot menunjukkan bahwa tidak ditemukan pola tertentu yang teratur dan titiktitik menyebar di atas dan di bawah angka 0 pada sumbu Y. Hal ini berarti tidak terjadi heteroskedastisitas pada model regresi.

\subsection{Analisis Regresi Linier Sederhana}

Analisis regresi linier sederhana digunakan untuk melihat besarnya pengaruh dari variabel bebas terhadap variabel terikat. Berikut ini adalah hasil analisis regresi sederhana dalam penelitian ini:

\section{Analisis Regresi sederhana biaya promosi terhadap hasil penjualan}

Tabel 7. Hasil Analisis Regresi Linier Sederhana Biaya Promosi Terhadap Hasil Penjualan

Coeffi ci entsa

\begin{tabular}{|c|c|c|c|c|c|}
\hline \multirow[b]{2}{*}{ Model } & \multicolumn{2}{|c|}{$\begin{array}{c}\text { Unstandardized } \\
\text { Coef f icients }\end{array}$} & $\begin{array}{l}\text { St andardized } \\
\text { Coef f icients }\end{array}$ & \multirow[b]{2}{*}{$\mathrm{t}$} & \multirow[b]{2}{*}{ Sig. } \\
\hline & $\mathrm{B}$ & St d. Error & Beta & & \\
\hline $1 \quad$ (Constant) & 7405,947 & 1364,445 & & 5,428 &, 000 \\
\hline Prom osi & 17,636 & 1,103 & ,939 & 15,983 &, 000 \\
\hline
\end{tabular}

a. Dependent Variable: Hasil

Berdasarkan hasil perhitungan didapat persamaan regresi $\mathrm{Y}=$ $7.405,947+17,636 \quad \mathrm{X} 1$.

Persamaan regresi tersebut dapat diartikan bahwa:

Konstansta sebesar $7.405,947$ dapat diartikan bahwa jika tidak ada biaya promosi maka hasil penjualan UD Bawang Goreng di Desa Pagedangan Kecamatan Adiwerna Kabupaten Tegal adalah sebesar Rp. 7.405,947

Analisis Regresi sederhana biaya distribusi terhadap hasil penjualan

Tabel 8. Hasil Analisis Regresi Linier Sederhana Biaya Distribusi Terhadap Hasil Penjualan

\section{Coeffi ci entsa}

\begin{tabular}{|c|c|c|c|c|c|}
\hline \multirow{2}{*}{ Model } & \multicolumn{2}{|c|}{$\begin{array}{l}\text { Unstandardized } \\
\text { Coef f icients }\end{array}$} & $\begin{array}{l}\text { St andardized } \\
\text { Coef f icients }\end{array}$ & \multirow[b]{2}{*}{$\mathrm{t}$} & \multirow[b]{2}{*}{ Sig. } \\
\hline & $\mathrm{B}$ & St d. Error & Beta & & \\
\hline $1 \quad$ (Constant) & $-4960,280$ & 1559,946 & & $-3,180$ & ,003 \\
\hline Distribusi & 9,937 & ,457 & ,966 & 21,747 &, 000 \\
\hline
\end{tabular}

a. Dependent Variable: Hasil 
Berdasarkan hasil perhitungan didapat persamaan regresi $\mathrm{Y}=-4.960,280$ + 9,937 X2. Persamaan regresi tersebut dapat diartikan bahwa:

Konstansta sebesar $-4.960,280$ dapat diartikan bahwa jika tidak ada biaya distribusi maka hasil penjualan UD Bawang Goreng di Desa Pagedangan Kecamatan Adiwerna Kabupaten Tegal adalah sebesar Rp. -4.960,280.

Koefisien regresi untuk biaya distribusi sebesar 9,937 bertanda positif artinya jika biaya distribusi meningkat Rp.1 sedangkan variabel lain tetap, maka akan menyebabkan peningkatan hasil penjualan UD Bawang Goreng di Desa Pagedangan Kecamatan Adiwerna Kabupaten Tegal sebesar Rp. 9,937.

\section{Uji Signifikansi Koefisien Regresi}

\section{Linier Sederhana}

Uji signifikansi koefisien regresi linier sederhana menunjukkan seberapa jauh pengaruh satu variabel independen secara individu dalam menerangkan variabel dependen.

Berdasarkan hasil perhitungan uji signifikansi koefisien regresi linier sederhana didapat hasil untuk variabel promosi (tabel 7) di peroleh nilai probabilitas signifikansi sebesar 0,000 yang lebih kecil dari 0,05 , artinya terdapat pengaruh yang signifikan promosi terhadap hasil penjualan. Sehingga dapat disimpulkan bahwa hipotesis pertama yang berbunyi "Diduga terdapat pengaruh biaya promosi terhadap hasil penjualan produk bawang goreng pada UD Bawang Goreng di Desa Pagedangan Kecamatan Adiwerna Kabupaten Tegal" terbukti kebenarannya.

Berdasarkan hasil perhitungan uji signifikansi koefisien regresi linier sederhana didapat hasil untuk variabel distribusi (tabel 8) di peroleh nilai probabilitas signifikansi sebesar 0,000 yang lebih kecil dari 0,05 , artinya terdapat pengaruh yang signifikan distribusi terhadap hasil penjualan. Sehingga dapat disimpulkan bahwa hipotesis kedua yang berbunyi "Diduga terdapat pengaruh biaya distribusi terhadap hasil penjualan produk bawang goreng pada UD Bawang Goreng di Desa Pagedangan Kecamatan Adiwerna Kabupaten Tegal" terbukti kebenarannya

\section{Analisis Regresi Linier Berganda}

Analisis regresi pada dasarnya adalah studi mengenai ketergantungan variabel dependen (terikat) dengan satu atau lebih variabel independen, dengan tujuan untuk mengestimasi atau memprediksi rata-rata populasi atau nilai rata-rata variabel dependen berdasarkan nilai variabel independen yang diketahui. Adapun persamaan untuk menguji hipotesis secara keseluruhan pada penelitian ini adalah sebagai berikut:

Tabel 9. Hasil Analisis Regresi Linier Berganda

Coeffici entsa

\begin{tabular}{|c|c|c|c|c|c|c|c|}
\hline \multirow{2}{*}{ Model } & \multicolumn{2}{|c|}{$\begin{array}{l}\text { Unstandardized } \\
\text { Coef f icients }\end{array}$} & \multirow{2}{*}{$\begin{array}{c}\begin{array}{c}\text { Standardized } \\
\text { Coef f icients }\end{array} \\
\text { Beta }\end{array}$} & \multirow{2}{*}{$\mathrm{t}$} & \multirow{2}{*}{ Sig. } & \multicolumn{2}{|c|}{ Collinearity Statistics } \\
\hline & $\overline{\mathrm{B}}$ & Std. Error & & & & Tolerance & VIF \\
\hline 1 (Constan) & $-1885,665$ & 1707,515 & & $-1,104$ & 277 & & \\
\hline Promosi & 6,043 & 1,943 & ,322 & 3,111 & ,004 &, 147 & 6,814 \\
\hline Distribusi & 6.878 & 1.065 & ,669 & 6.460 & .000 &, 147 & 6,814 \\
\hline
\end{tabular}

a. Dependent Variable: Hasil 
Berdasarkan hasil perhitungan didapat persamaan regresi $\mathrm{Y}=-1.885,665$ $+6,043 \mathrm{X} 1+6,878 \mathrm{X} 2$. Persamaan regresi tersebut dapat diartikan bahwa:

Konstansta sebesar $-1.885,665$ dapat diartikan bahwa jika tidak ada biaya promosi dan biaya distribusi maka hasil penjualan UD Bawang Goreng di Desa Pagedangan Kecamatan Adiwerna Kabupaten Tegal adalah sebesar Rp. $-1.885,665$.

Koefisien regresi untuk biaya promosi sebesar 6,043 bertanda positif artinya jika biaya promosi meningkat Rp.1 sedangkan variabel lain tetap, maka akan menyebabkan peningkatan hasil penjualan UD Bawang Goreng di Desa Pagedangan Kecamatan
Adiwerna Kabupaten Tegal sebesar Rp. 6,043.

Koefisien regresi untuk biaya distribusi sebesar 6,878 bertanda positif artinya jika biaya distribusi meningkat Rp.1 sedangkan variabel lain tetap, maka akan menyebabkan peningkatan hasil penjualan UD Bawang Goreng di Desa Pagedangan Kecamatan Adiwerna Kabupaten Tegal sebesar Rp. 6,878.

Uji Signifikansi Koefisien Regresi Linier Berganda

Uji simultan (Uji F) menunjukkan apakah semua variabel independen yang dimasukkan dalam model mempunyai pengaruh secara simultan terhadap variabel dependen.

Tabel 10. Hasil Uji Signifikansi Koefisien Regresi Linier Bergand ANOVAb

\begin{tabular}{|c|c|c|c|c|c|}
\hline Model & $\begin{array}{l}\text { Sum of } \\
\text { Squares }\end{array}$ & $\mathrm{df}$ & Mean Square & $\mathrm{F}$ & Sig. \\
\hline $1 \quad$ Regression & 1272100528 & 2 & 636050264,0 & 301,636 &, $000 \mathrm{a}$ \\
\hline Residual & 69586036,44 & 33 & 2108667,771 & & \\
\hline Total & 1341686564 & 35 & & & \\
\hline
\end{tabular}

a. Predictors: (Constant), Dist ribusi, Promosi

b. Dependent Variable: Hasil

Berdasarkan hasil uji pengaruh secara simultan diperoleh angka signifikansi sebesar $0,000<0,05$ artinya ada pengaruh yang signifikan antara biaya promosi dan biaya distribusi secara bersama-sama terhadap hasil penjualam. Sehingga dapat dikatakan hipotesis ketiga yang berbunyi "Diduga terdapat pengaruh biaya promosi dan biaya distribusi secara bersama-sama terhadap hasil penjualan produk bawang goreng pada UD Bawang Goreng di Desa Pagedangan Kecamatan Adiwerna Kabupaten Tegal" terbukti kebenarannya.

\section{Koefisien Determinasi}

Nilai koefisien determinasi (R2) menunjukkan persentase pengaruh semua variabel independen secara simultan terhadap variabel dependen. Koefisien determinasi (R2) dapat dicari dengan formulasi: Besarnya koefisien determinasi adalah 0 sampai dengan 1. Semakin mendekati nol, semakin kecil pula pengaruh semua variabel independen (X) terhadap nilai variabel dependen (dengan kata lain semakin kecil kemampuan model dalam menjelaskan perubahan nilai variabel dependen). Sedangkan jika koefisien determinasi mendekati satu, maka sebaliknya. 
Tabel 11. Hasil Analisis Koefisien Determinasi Model Summaryb

\begin{tabular}{|l|r|r|r|c|c|}
\hline Model & \multicolumn{1}{|c|}{$\mathrm{R}$} & R Square & $\begin{array}{c}\text { Adjusted } \\
\text { R Square }\end{array}$ & $\begin{array}{l}\text { St d. Error of } \\
\text { the Estimate }\end{array}$ & $\begin{array}{c}\text { Durbin- } \\
\text { Wat son }\end{array}$ \\
\hline 1 &, $974 \mathrm{a}$ &, 948 &, 945 & 1452,12526 & 1,596 \\
\hline
\end{tabular}

a. Predictors: (Constant), Distribusi, Prom osi b. Dependent Variable: Hasil

Dari hasil perhitungan uji koefisien determinasi menggunakan program SPSS dapat diketahui nilai koefisien determinasi sebesar 0,948 atau 94,8\%. Nilai koefisien determinasi sebesar 94,8 $\%$ tersebut mengandung arti bahwa biaya promosi dan biaya distribusi secara bersama-sama memberikan kontribusi atau berpengaruh langsung terhadap hasil penjualan produk bawang goreng pada UD Bawang Goreng di Desa Pagedangan Kecamatan Adiwerna Kabupaten Tegal sebesar 94,8\% dan sisanya 5,2\% tidak bisa dijelaskan dalam penelitian ini.

\section{KESIMPULAN DAN SARAN}

\section{Kesimpulan}

Berdasarkan hasil penelitian yang telah dilakuakan, maka dapat diambil kesimpulan sebagai berikut :

Berdasarkan hasil perhitungan analisis regresi linier sederhana didapat hasil untuk variabel promosi di peroleh nilai probabilitas signifikansi sebesar 0,000 yang lebih kecil dari 0,05 , artinya terdapat pengaruh promosi terhadap hasil penjualan. Sehingga dapat disimpulkan bahwa hipotesis pertama yang berbunyi "Diduga terdapat pengaruh biaya promosi terhadap hasil penjualan produk bawang goreng pada UD Bawang Goreng di Desa Pagedangan Kecamatan Adiwerna Kabupaten Tegal" terbukti kebenarannya.

Berdasarkan hasil perhitungan analisis regresi linier sederhana didapat hasil untuk variabel distribusi di peroleh nilai probabilitas signifikansi sebesar 0,000 yang lebih kecil dari
0,05 , artinya terdapat pengaruh distribusi terhadap hasil penjualan. Sehingga dapat disimpulkan bahwa hipotesis kedua yang berbunyi "Diduga terdapat pengaruh biaya distribusi terhadap hasil penjualan produk bawang goreng pada UD Bawang Goreng di Desa Pagedangan Kecamatan Adiwerna Kabupaten Tegal" terbukti kebenarannya.

Berdasarkan hasil uji pengaruh secara simultan diperoleh angka signifikansi sebesar $0,000<0,05$ artinya ada pengaruh antara biaya promosi dan biaya distribusi secara bersama-sama terhadap hasil penjualam. Sehingga dapat dikatakan hipotesis ketiga yang berbunyi:

Diduga terdapat pengaruh biaya promosi dan biaya distribusi secara bersama-sama terhadap hasil penjualan produk bawang goreng pada UD Bawang Goreng di Desa Pagedangan Kecamatan Adiwerna Kabupaten Tegal” terbukti kebenarannya.

Saran

Berdasarkan kesimpulan dari penelitian ini, maka dapat diberikan beberapa saran sehubungan dengan penelitian ini, yaitu :

Sebaiknya UD Bawang Goreng di Desa Pagedangan Kecamatan Adiwerna Kabupaten Tegal menambah biaya promosi mengingat biaya promosi dapat meningkatkan volume penjualan. Apabila volume penjualan sudah mencapai target yang ditentukan, UD Bawang Goreng di Desa Pagedangan Kecamatan Adiwerna 
Kabupaten Tegal harus menjaga kestabilan biaya promosi agar biaya promosi tidak membengkak.

Sebaiknya UD Bawang Goreng di Desa Pagedangan Kecamatan Adiwerna Kabupaten Tegal menambah biaya distribusi mengingat biaya distribusi dapat meningkatkan volume penjualan. Biaya distribusi dapat ditingkatkan beriringan dengan meningkatnya volume penjualan, misalnya dengan memperluas daerah distribusi.

\section{DAFTAR PUSTAKA}

Arikunto, Suharsimi. 2010. Prosedur Penelitian. Edisi Revisi IV. Jakarta: Rineka Cipta.

Ghozali, Imam. 2016. Aplikasi Analisis Multivariate Dengan Program IBM SPSS. 23. Semarang: Badan Penerbit Universitas Diponegoro.

Kadir. 2015. Statistika Terapan : Konsep, Contoh, dan Analisa Data dengan. Program SPSS/Lisrel dalam Peneltian. Jakarta : PT Rajagrafindo Persada

Kismono, Gugup. 2011. Pengantar Bisnis. Yogyakarta: BPFE.

Kotler, Philip dan Lane Keller. 2013. Prinsip-Prinsip Manajemen Pemasaran. Jakarta : Salemba Empat.

Laksana, Fajar. 2008. Manajemen Pemasaran. Yogyakarta: Penerbit Graha Ilmu. Lupiyoadi, Rambat. 2013. Manajemen Pemasaran Jasa. Jakarta: Salemba. Empat.

Moy, Ignasius Yenglie. 2015. Pengaruh Biaya Promosi Terhadap Volume Penjualan Chez Moka Coffee Shop.

Online. www.repository.telkomuniversity.ac.id. Mulyadi. 2009. Akuntansi Biaya. Yogyakarta: UPPAMP YKPN.

Rahmanita, Maulidina. 2017. Pengaruh Biaya Promosi Dan Biaya Produksi Terhadap Laba Bersih Dengan Volume Penjualan Sebagai Variabel Intervening. Online. http://eprints.iain- surakarta.ac.id/Maulidina Rahmanita.pdf

Rangkuti, Freddy. 2009. Strategi Promosi yang Kreatif dan Analisis Kasus Integrated Marketing. Jakarta: Gramedia Pustaka Utama.

Rangkuti, Freddy. 2009. Strategi Promosi yang Kreatif dan Analisis Kasus. Integrated Marketing. Jakarta: Gramedia Pustaka Utama.

Rudianto. 2009. Akuntansi Manajemen. Yogyakarta: Grasindo

Soetrisno, Edy. 2011. Manajemen Sumber Daya Manusia, Jakarta: Kencana.

Stanton, William J. 2003. Prinsip Pemasaran. Alih Bahasa oleh Sadu Sundaru. Jilid Satu. Edisi Kesepuluh. Jakarta : Erlangga.

Sudjana. 2005: Motoda Statistika. Bandung: Tarsito.

Sugiyono. 2010. Statistik Untuk Penelitian. Bandung: Alfabeta 
Sumarni, Murti dan John Soeprihanto. 2003. Pengantar bisnis (Dasar-Dasar Ekonomi Perusahaan). Yogyakarta: Liberty.

Sunyoto, Danang. 2012. Dasar-Dasar Manajemen Pemasaran. Jakarta: CAPS.

Suyanto. 2009. Strategi Penjualan Perseorangan dan Pemasaran Langsung. Jakarta: CAPS. Swasta, Basu dan Irawan. 2008. Manajemen Pemasaran Modern. Yogyakarta: Liberty.

Swastha, Basu dan Ibnu Sukotjo. 2002. Pengantar Bisnis Modern. Edisi Ketiga,. Yogyakarta: Liberty

Swastha, Basu. 2009. Asas-asas Marketing. Edisi 3. Yogyakarta: Liberty. Tjiptono, Fandy. 2008. Strategi Pemasaran. Edisi 3. Yogyakarta: ANDI.

Wardana, Ida Bagus Komang Ary. 2015. Pengaruh Biaya Promosi Terhadap Volume Penjualan Patung UD. Taksu Bali Di Desa Panji Periode TAHUN 2012 - 2017. Online. https://ejournal.undiksha.ac.id/ index.php/JJPE/article/view/6404

Widnyana, Made Juni. 2017. Pengaruh Biaya Promosi Dan Biaya Distribusi Terhadap Laba Ud Surya Logam Desa Temukus Tahun 2010-2012. Online. https://ejournal.undiksha.ac.id/index.php/JJPE/article/view/1903 